\title{
CLINICAL AND EPIDEMIOLOGICAL CHARACTERISTICS OF INJURIES CAUSED BY VENOMOUS SNAKES OBSERVED AT THE HOSPITAL FOR TROPICAL DISEASES OF ARAGUAÍNA, TOCANTINS STATE, BRAZIL, FROM 1995 TO 2000
}

\author{
PAULA NETO J. B. (1), RIBEIRO R. S. P. (1), LUZ J. A. (1), GALVÃO M. (1), \\ CARVALHO S. M. D. (1), HADDAD JUNIOR V. (2)
}

(1) Hospital for Tropical Diseases, Araguaína,Tocantins, Brazil; (2) Botucatu School of Medicine, São Paulo State University, UNESP, Botucatu, São Paulo State, Brazil.

ABSTRACT: Injuries caused by venomous snakes are considered a problem of public health in Brazil, and further studies for a better knowledge are very important. The aim of this work is to describe clinical and epidemiological characteristics that were observed from 1995 to 2000 in the Hospital for Tropical Diseases of Araguaína, Tocantins State, Brazil, which is a unit of health that takes care of patients suffering from tropical diseases. We studied 440 individuals and the most common characteristics observed were masculine sex, age among 15-45 years, bite in low members, and injuries caused by snakes of the Bothrops genus. The signs and symptoms more frequently observed were edema, pain, erythema, and bleeding. The most observed systemic manifestation was alteration of blood coagulation. The most frequent complications were abscess, necrosis, bacterial infection, and renal failure. The mortality rate was $3 \%$. These data are very important for the evaluation of the problem.

KEY WORDS: snakebite, Tocantins State, Brazil, epidemiology.

\section{CORRESPONDENCE TO:}

JOÃO BATISTA DE PAULA NETO, Rua Hudson, 325, 14024-000, Ribeirão Preto, São Paulo, Brasil, Phone: 5516 91568353, Email: salespaula@uol.com.br. 
J. B. Paula Neto et al. CLINICAL AND EPIDEMIOLOGICAL CHARACTERISTICS OF INJURIES CAUSED BY VENOMOUS SNAKES OBSERVED AT THE HOSPITAL FOR TROPICAL DISEASES OF ARAGUAÍNA, TOCANTINS STATE, BRAZIL, FROM 1995 TO 2000. J. Venom. Anim. Toxins incl. Trop. Dis., 2005, 11, 4, p. 423

\section{INTRODUCTION}

The injuries caused by venomous snakes are an important public health problem in underdeveloped countries, mainly in tropical areas, for their frequency and potential severity, affecting about a million people annually, with a mortality rate from 30 to 50 thousand. In Brazil, 20,000 cases are considered to happen annually, and 81,611 cases were notified between 1990 and $1993(12,13)$, with a death index of $0.43 \%$. This data is noteworthy: 90,000 cases of envenomation by snakes are estimated to occur annually causing 2,000 deaths (1-17). Brazil presents the highest annual index of injuries in South America.

About $75 \%$ of the notified cases are attributed to snakes of the Bothrops genus, $7 \%$ to the Crotalus genus, $1.5 \%$ to the Lachesis genus, $0.5 \%$ to the Micrurus genus, and $13 \%$ to non-venomous snakes. The Hospital for Tropical Diseases, located in the municipal district of Araguaína, Tocantins State, is a reference center for tropical diseases, (and, consequently, snake envenomations), assisting patients from a macro-area that encompasses the north of Tocantins, south of Pará and south of Maranhão State. Until the moment, the snakes identified in Tocantins State were of the genera Bothrops (B. atrox, B. neuwiedi and B. moojeni), Crotalus (C. durissus), and Micrurus ( $M$. frontalis, M. lemniscatus). In Pará State, the genera Bothrops (B. atrox, B. neuwiedi), Crotalus (C. durissus), Micrurus (M. lemniscatus, $M$. surinamensis, M. spixii), and Lachesis (L. muta) have been reported; and in the state of Maranhão, snakes of the genera Bothrops (B. atrox, B. neuwiedi, B. moojeni), Crotalus (C. durissus), Micrurus ( $M$. ibiboboca, M. lemniscatus, $M$. surinamensis, and M. spixii), and Lachesis (L. muta) have been recorded.

There are no reports on injuries by venomous snakes in Tocantins State. The aim of this work was to determine the clinical and epidemiological profile of victims of venomous snakes assisted in our hospital, contributing to the knowledge of the clinical characteristics of these injuries; and also to evaluate the epidemiological data in the area studied; to identify areas of higher incidence; to create effective measures that help to improving the assistance to these patient; and to emphasize the importance of preventive measures in the patients' municipal districts.

\section{PATIENTS AND METHODS}

Data were obtained initially from the analysis of handbooks and records of notification of accidents by venomous animals (Records of Investigation, Sistema Nacional de 
J. B. Paula Neto et al. CLINICAL AND EPIDEMIOLOGICAL CHARACTERISTICS OF INJURIES CAUSED BY VENOMOUS SNAKES OBSERVED AT THE HOSPITAL FOR TROPICAL DISEASES OF ARAGUAÍNA, TOCANTINS STATE, BRAZIL, FROM 1995 TO 2000. J. Venom. Anim. Toxins incl. Trop. Dis., 2005, 11, 4, p. 424

Atendimento Médico - SINAM) of patients assisted at the Hospital for Tropical Diseases of Araguaína, Tocantins State, Brazil, from 1995 to 2000. The following variables were analyzed:

A) Epidemiological data: Analysis of data from patients assisted in our hospital, such as: age, sex, profession, bite site, time elapsed between the bite and the arrival at the hospital.

B) Clinical data: The local symptoms considered were pain, edema, erythema, blisters, ecchymosis, and bleeding at the bite site. The systemic manifestations observed were nausea, vomiting, dizziness, migraine, vision alterations, myalgia, renal function alterations, dyspnea, and alterations in the blood coagulation time. We also evaluated the diagnosis, the patients' clinical evolution, and the therapeutic measure: serum therapy (serum type, dose, and administration route).

\section{RESULTS}

Out of the 440 cases of injuries by venomous snakes, $307(69.77 \%)$ were identified as being caused by the Bothrops genus, $80(18.18 \%)$ by the Crotalus genus, and 53 (12.04\%) were identified or considered as injuries caused by non-venomous snakes. There were no records of accidents caused by Micrurus and Lachesis genera (Figure 7).

Diagnosis of the accidents was based on the snake identification or on the signs and clinical symptoms of envenomation presented by the patients. The municipal districts of larger occurrence were:

1) Bothops genus: Araguaína, 107 cases (34.8\%); Santa Fé do Araguaia, 37 cases (12\%); Aragominas, 21 cases (6.8\%); Nova Olinda, 17 cases (5.5\%); Piraquê, 14 cases (4.5\%); Muricilândia and Pau d'Arco, 12 cases each (3.9\%); Babaçulândia, 10 cases (3.2\%); Xinguara (PA), 9 cases (2.9\%); Palmeirante, 8 cases (2.6\%); and Wanderlândia, 6 cases (1.9\%). Other municipal districts involved in the study showed less than 5 cases during the evaluated period: Araguanã - 4, Filadelfia - 4, Goiatins - 4, Arapoema - 3, Conceição do Araguaia (PA) - 3, Bandeirantes - 3, Cachoeirinha - 3, Angico - 3, Carolina (MA) - 2, Guaraí - 2, Pequizeiro - 2, Redenção (PA) - 2, São Geraldo (PA) - 2, Araguatins - 1, Benedito Leite (MA) - 1, Estreito (MA) - 1, Itapiratins - 1, Jacilândia - 1, Itaporã - 1, Recursolândia - 1, São Bento - 1, São Domingos do Araguaia (PA) - 1, Tupiratins - 1, Couto Magalhães - 1, Araguacema - 
J. B. Paula Neto et al. CLINICAL AND EPIDEMIOLOGICAL CHARACTERISTICS OF INJURIES CAUSED BY VENOMOUS SNAKES OBSERVED AT THE HOSPITAL FOR TROPICAL DISEASES OF ARAGUAÍNA, TOCANTINS STATE, BRAZIL, FROM 1995 TO 2000. J. Venom. Anim. Toxins incl. Trop. Dis., 2005, 11, 4, p. 425

1, Barra do Ouro - 1, Rio Sono - 1, Riachinho - 1, Lago do São Bento - 1 (Figures 1, 3 and 4).

2) Crotalus genus: Araguaína, 14 cases (17.5\%); Babaçulândia, 7 cases (8.7\%); Nova Olinda, 4 cases (5\%); Piraquê, 4 cases (5\%); Wanderlândia, 4 cases (5\%); Xambioá, 3 cases (3.7\%); São Geraldo (PA), 3 cases (3.7\%); Pedro Afonso, 3 cases (3.7\%); Estreito (MA), 2 cases (2.5\%); Filadelfia, 2 cases (2.5\%); Palmeirante, 2 cases (2.5\%); Recursolândia, 2 cases (2.5\%); Tupiratins, 2 cases (2.5\%); Porto Franco (MA), 2 cases (2.5\%); Santa Maria das Barreiras (PA), 2 cases (2.5\%). There was just one case recorded in each of the remaining municipal districts involved: Cachoeirinha, Goiatins, Guaraí, Itaguatins, Mosquito, Muricilândia, Maurilândia do Tocantins, Palmeira do Tocantins, Rio Sono, Riachão (MA), Palmas, Augustinopólis, Bandeirantes, Darcinópolis, Paraíso do Tocantins, Pau d'Arco, Porto Franco (MA), Rio Maria (PA), Barra do Ouro, Santa Terezinha do Tocantins (Figures 2, 5 and 6).

There was prevalence of accidents in males, 342 cases (77.72\%), in relation to females, 98 cases (22.27\%). Considering the age group, the largest number of envenomations happened between 11 and 45 years (67.89\%). In relation to the time elapsed between the accident and the medical service, 67.49\% cases received medical aid between 3 and 7 hours after the bite.

The highest number of accidents - 276 cases (62.71\%) - happened during the day, between 6 a.m. and 6 p.m. In the night period, 64 cases (25.9\%) occurred. From the accidents, 234 (53.18\%) happened during work in the rural area, 97 (22.04\%) during leisure, and $109(24.77 \%)$ in other activities. Regarding the time of the year, the period of highest incidence of accidents was between the months of December and April (54\%); and the lowest incidence occurred from July to September (15\%) (Figures 8 and 9). In relation to the clinical data, the most affected corporal segments were the feet in 268 cases (60.9\%) and the legs in 92 cases (20.9\%), followed by the hands in 25 cases (5.68\%).

The most frequent clinical local manifestations were:

a) Bothrops genus: pain in 296 cases (96.41\%), edema in 294 cases (95.76\%), erythema in 160 cases (52.11\%), ecchymosis in 82 cases $(26.71 \%)$, and local bleeding in 61 cases (19.86\%).

b) Crotalus genus: pain in the bite site in 65 cases (81.25\%), edema in 45 cases (56.25\%), erythema in 18 cases (22.5\%), and local bleeding in 10 cases (12.5\%). 
J. B. Paula Neto et al. CLINICAL AND EPIDEMIOLOGICAL CHARACTERISTICS OF INJURIES CAUSED BY VENOMOUS SNAKES OBSERVED AT THE HOSPITAL FOR TROPICAL DISEASES OF ARAGUAÍNA, TOCANTINS STATE, BRAZIL, FROM 1995 TO 2000. J. Venom. Anim. Toxins incl. Trop. Dis., 2005, 11, 4, p. 426

c) Non-venomous snakes: pain in 41 cases (77.35\%) and edema in 22 cases $(41.5 \%)$.

The most frequent systemic manifestations were:

a) Bothrops genus: myalgia in 66 cases (21.49\%), vomiting in 65 cases $(21.17 \%)$, dark urine in 61 cases (19.86\%), oliguria in 37 cases (12.05\%), and migraine in 21 cases (6.8\%).

b) Crotalus genus: palpebral ptosis in 75 cases (93.75\%), myalgia in 59 cases (73.75\%), dark urine in 52 cases (65\%), oliguria in 34 cases (42.5\%), and diplopia in 40 cases $(50 \%)$.

c) Non-venomous snakes: myalgia and dark urine in 6 cases $(11.32 \%)$.

Coagulation time was determined in all the assisted cases and it was shown to be altered (higher than 10 minutes or non-coagulable) in 99 (32.24\%) cases of Bothrops bites, $22(27.5 \%)$ cases of Crotalus bites, and one (1.8\%) case of non-venomous snakebite.

With regard to the cases evolution, 401 patients (91.13\%) obtained cure, 11 patients (2.5\%) were transferred to another hospital for surgical procedures or for hospitalization in the Intensive Therapy Unit, 14 patients (3.18\%) were at death, and there was no evolutionary segment for 14 patients (3.18\%). Among the deaths, 3 cases $(0.68 \%)$ were due to Bothrops genus bites and 11 cases $(2.5 \%)$ due to Crotalus genus.

Considering the treatment, 361 patients (82.5\%) received serum therapy. The same was applied to cases with clinical and/or laboratorial signs of envenomation either without previous serum therapy or with previous serum therapy administered at the patient's district by an inadequate route (intramuscular) and/or in doses inferior to the case severity.

The administration route was the intravenous in all the cases. The number of flasks used varied according to the case severity and the accident type. For secondary bacterial infection, analgesics, anti-inflammatory and antibiotics, as well as tetanus prevention and nursing of the wound site, were used in cases where there was no history of previous inoculation. Surgical treatment was applied to patients who developed abscesses in the bite site. 
Figure 1: A specimen of Bothrops captured near Araguaína after causing envenomation in a man. This genus caused most of the injuries in this study.

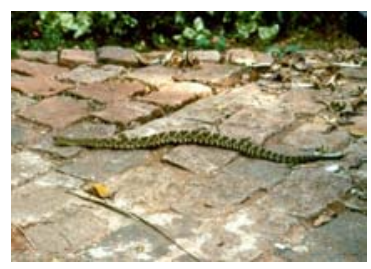

Figure 2: Crotalus durissus. The rattlesnakes were responsible for a number of injuries in the study area greater than that from the Ministry of Health for all the country.

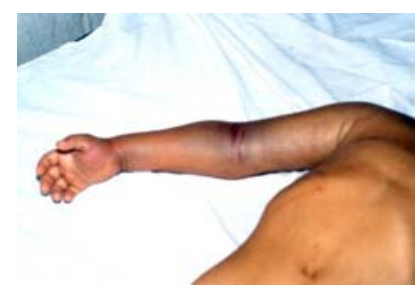

Figure 3: The arm of a victim bitten by a Bothrops snake. Note the edema, erythema and ecchymosis.

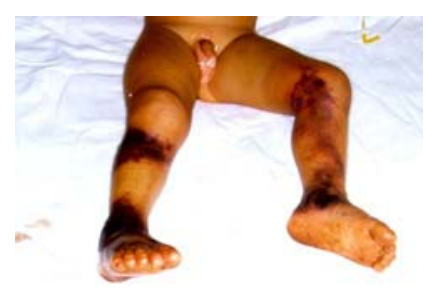

Figure 4: A severe accident with prominent bleeding (uncoagulable blood) caused by a Bothrops snake in a child. 
J. B. Paula Neto et al. CLINICAL AND EPIDEMIOLOGICAL CHARACTERISTICS OF INJURIES CAUSED BY VENOMOUS SNAKES OBSERVED AT THE HOSPITAL FOR TROPICAL DISEASES OF ARAGUAÍNA, TOCANTINS STATE, BRAZIL, FROM 1995 TO 2000. J. Venom. Anim. Toxins incl. Trop. Dis., 2005, 11, 4, p. 428

Figure 5: Palpebral ptosis is a prominent aspect in envenoming by snakes of the Crotalus genus. This patient was observed during this study.

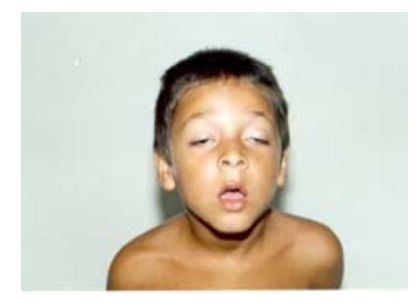

Figure 6: This child showed intense neurotoxicity with palpebral ptosis after being bitten by a Crotalus snake.

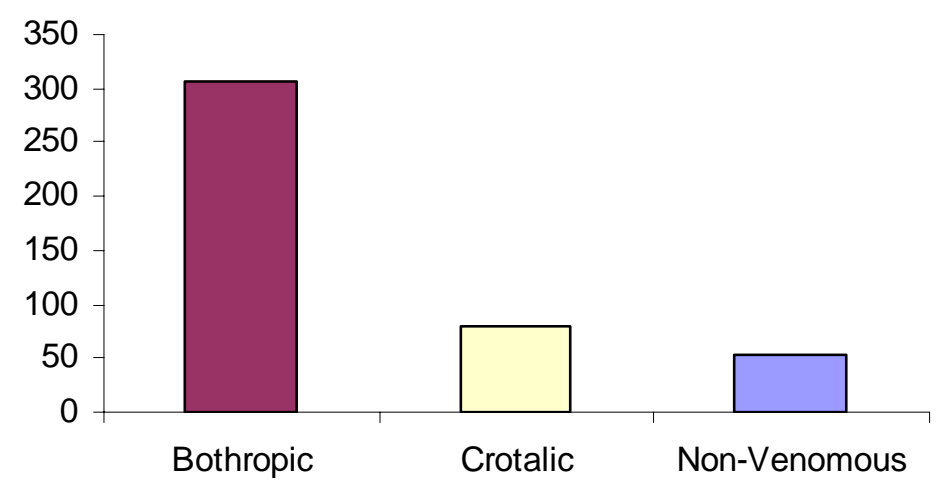

Figure 7: Distribution of ophidic accidents according to the snake genus. 
J. B. Paula Neto et al. CLINICAL AND EPIDEMIOLOGICAL CHARACTERISTICS OF INJURIES CAUSED BY VENOMOUS SNAKES OBSERVED AT THE HOSPITAL FOR TROPICAL DISEASES OF ARAGUAÍNA, TOCANTINS STATE, BRAZIL, FROM 1995 TO 2000. J. Venom. Anim. Toxins incl. Trop. Dis., 2005, 11, 4, p. 429

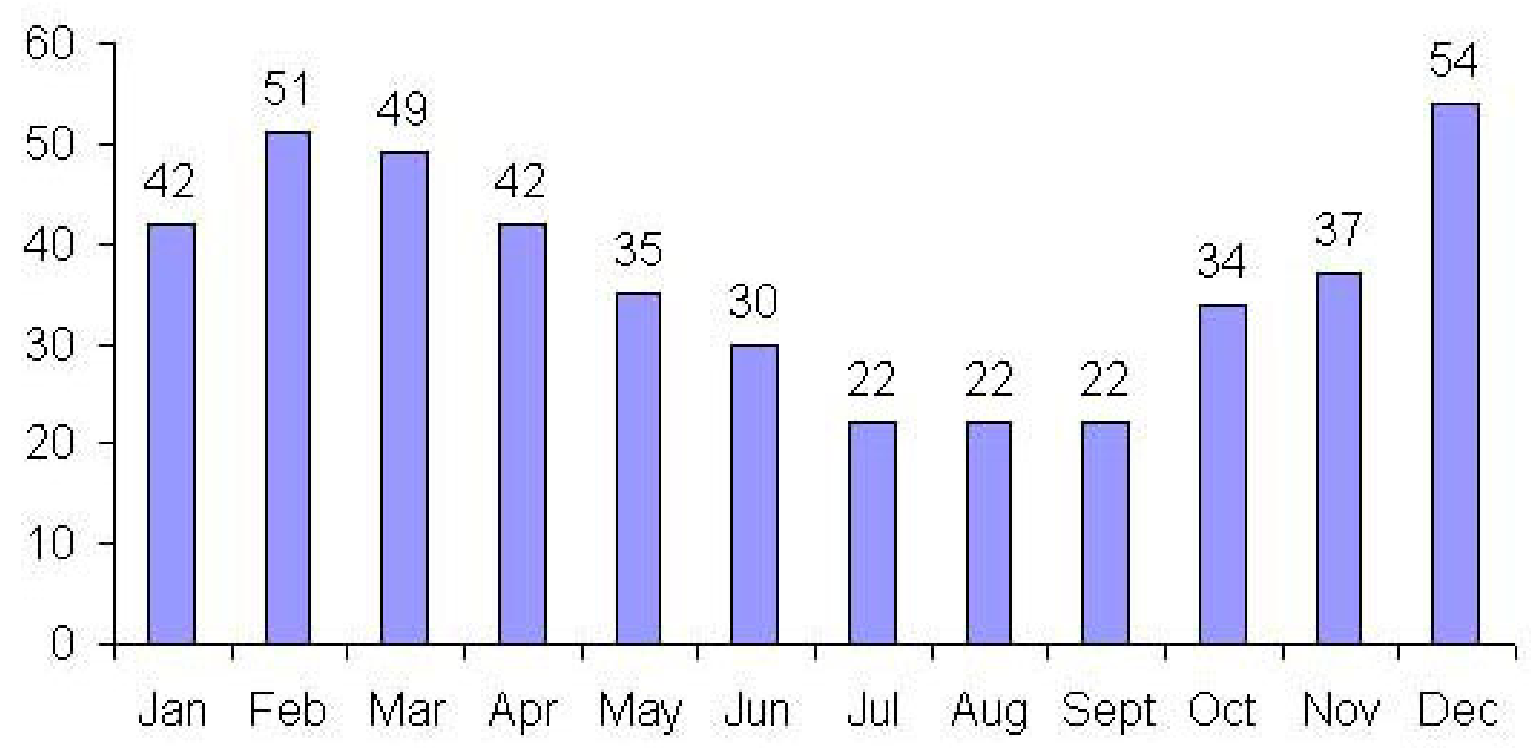

(Months)

Figure 8: Distribution of accidents according to the month of occurrence.

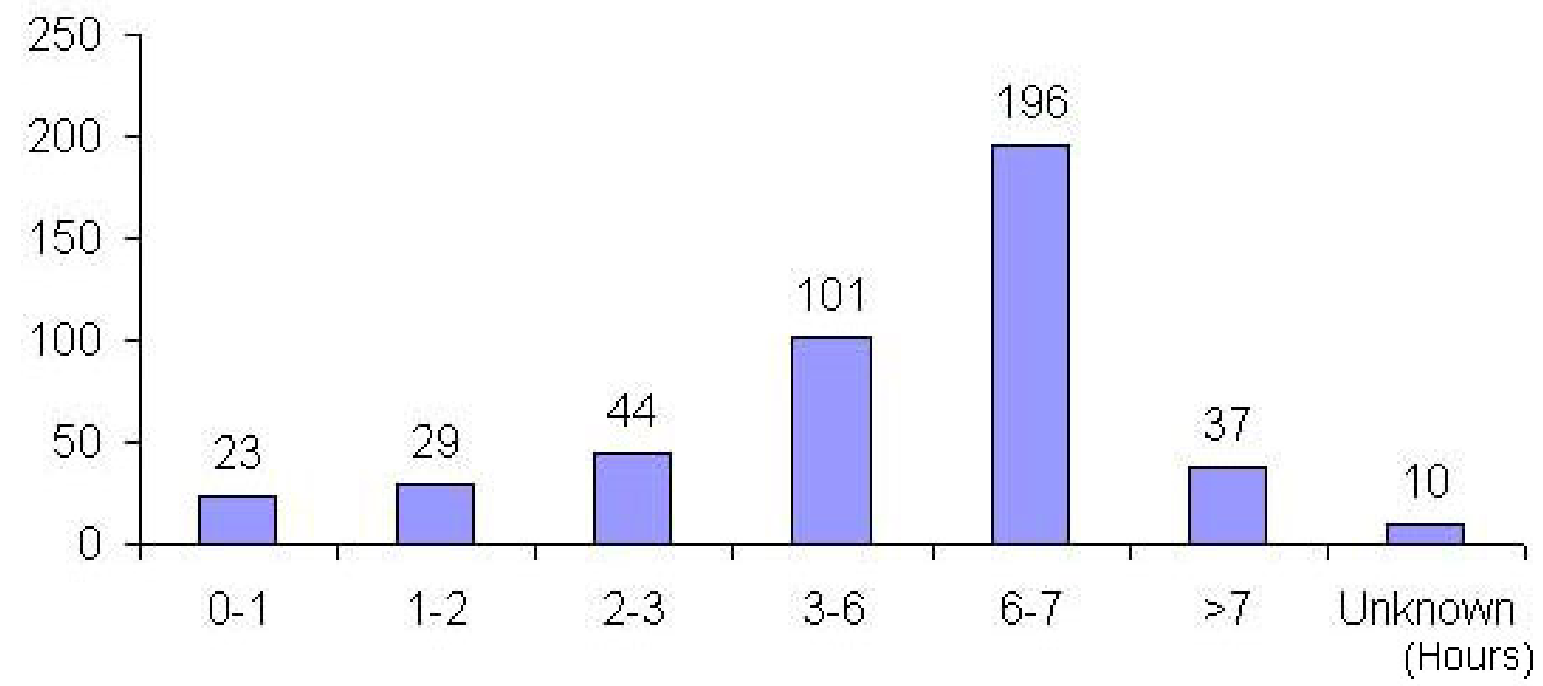

Figure 9: Distribution of accidents according to the time elapsed between the bite and the medical aid.

\section{DISCUSSION}

The results obtained, in spite of not reflecting all the accidents in Tocantins State, demonstrate a larger number of Crotalus bites when compared to the data notified and recorded all over the national territory according to the Ministry of Health (7\%). However, most of the accidents are caused by the Bothrops genus (69.77\%), what coincides with the data from the Ministry of Health (75\%) (Figure 7).

Most bites occurred in the municipal district of Araguaína, located to the north of Tocantins State, characterized by 2 much defined seasons, a rainy one and a dry 
J. B. Paula Neto et al. CLINICAL AND EPIDEMIOLOGICAL CHARACTERISTICS OF INJURIES CAUSED BY VENOMOUS SNAKES OBSERVED AT THE HOSPITAL FOR TROPICAL DISEASES OF ARAGUAÍNA, TOCANTINS STATE, BRAZIL, FROM 1995 TO 2000. J. Venom. Anim. Toxins incl. Trop. Dis., 2005, 11, 4, p. 430

one, besides two types of vegetation: forests and open areas (savannahs) composed of arboreal vegetation. Other areas with a high number of bites by Bothrops were the municipal districts of Santa Fé do Araguaia and Aragominas, which present as geoclimatic characteristics a rainy climate and exuberant vegetation formed by forests. Regarding Crotalus bites, the municipal districts with larger number of bites were Babaçulândia, Nova Olinda, Piraquê, and Wanderlândia that present open areas, composed of savannahs and mountains.

According to the time of the year, the bites were more frequent from December to April, which are the rainy months in the region, when the planting period begins and, consequently, there is movement of people and also of snakes in the fields. Another practice in the area is the deforestation for subsequent planting, which causes the man to be in contact with the snakes of the area (Figure 8). The accidents happened, in their majority (62.7\%), during the day, which is the period of higher human activity. With regard to the sex, there was a higher incidence of attacks on men than on women, which shows a similarity to other Brazilian studies. This fact could be explained by the male's larger presence in agricultural activities.

The predominant age group (67.89\%) was composed of youths and young adults (11 to 45 years), who constitute the primary share of manpower in the rural area. It was observed that $12 \%$ of the bites occurred in children up to 10 years old, who could have been in the area working or accompanying their parents at work. In relation to the circumstances of the accidents, 53.1\% happened during the patients' professional activities and the remaining in leisure activities and others.

A high number of patients lived in the rural area, and the distance from the urban centers determined the medium time of medical assistance after the accident, which was between 3 and 7 hours (67.49\%). The bites happened in more distant municipal districts, especially those out of Tocantins State, and contributed to the medical aid only 7 hours after the accident (Figure 9).

Confirming previous works and the statistics already existent, this study showed that the most affected anatomical sites in the accidents were the feet (60.9\%), legs (20.9\%), and hands (5.68\%). It is interesting to notice that the bites in the hands occurred during the hunt of animals like armadillo, which lives in pits in the ground where there are also snakes, especially of the Bothrops genus.

Considering the clinical aspects, in cases of Bothrops bites there was prevalence of local alterations, characteristic of these kinds of accidents. However, in Crotalus 
J. B. Paula Neto et al. CLINICAL AND EPIDEMIOLOGICAL CHARACTERISTICS OF INJURIES CAUSED BY VENOMOUS SNAKES OBSERVED AT THE HOSPITAL FOR TROPICAL DISEASES OF ARAGUAÍNA, TOCANTINS STATE, BRAZIL, FROM 1995 TO 2000. J. Venom. Anim. Toxins incl. Trop. Dis., 2005, 11, 4, p. 431

bites, pain was observed at the bite site in 65 cases (14.7\%) and edema in 45 cases (10.2\%), what generally are not described because local alterations produced by Crotalus venom have small expression.

Death was present in $3 \%$ of the total cases (14), with prevalence in Crotalus envenomations (78\% of the deaths).

\section{ACKNOWLEDMENTS}

The authors are thankful to Dr. Benedito Barraviera for the suggestions that improved the text.

\section{REFERENCES}

1 BARRAVIERA B. Ed. Venenos: aspectos clínicos e terapêuticos dos acidentes por animais peçonhentos. Rio de Janeiro: EPUB, 1999. 411p.

2 BORGES CC., SADAHIRO M., SANTOS MC. Aspectos epidemiológicos e clínicos dos acidentes ofídicos ocorridos nos municípios do Estado do Amazonas. Rev. Soc. Bras. Med. Trop., 1999, 32, 637-46.

3 BRASIL. Ministério da Saúde. Fundação Nacional da Saúde. Guia de vigilância epidemiológica. 5.ed. Brasília, 2002. 842p.

4 BRASIL. Ministério da Saúde. Fundação Nacional da Saúde. Manual de diagnóstico e tratamento de acidentes por animais peçonhentos. 2.ed. Brasília, 2001. 112p.

5 CAIAFFA WT., ANTUNES CMF., OLIVEIRA HR., DINI CR. Aspectos epidemiológicos e clínicos dos acidentes ofídicos atendidos em hospital referência em Belo Horizonte, Minas Gerais, Brasil (1980-1986). Rev. Inst. Med. Trop. S. Paulo, 1997, 39, 113-8.

6 CARDOSO JLC., FRANÇA FOS., WEN FH., MÁLAQUE CMS., HADDAD Jr. V. Eds. Animais peçonhentos no Brasil: biologia, clínica e terapêutica dos acidentes. São Paulo: Sarvier, 2003. 466p.

7 CARVALHO MA., NOGUEIRA F. Serpentes da área urbana de Cuiabá, Mato Grosso: aspectos ecológicos e acidentes ofídicos associados. Cad. Saúde Públ., 1998, 14, 753-63.

8 FEITOSA RFG., MELO IMLA., MONTEIRO HSA. Epidemiologia dos acidentes por serpentes peçonhentas no Estado do Ceará - Brasil. Rev. Soc. Bras. Med. Trop., 1997, 30, 295-301. 
J. B. Paula Neto et al. CLINICAL AND EPIDEMIOLOGICAL CHARACTERISTICS OF INJURIES CAUSED BY VENOMOUS SNAKES OBSERVED AT THE HOSPITAL FOR TROPICAL DISEASES OF ARAGUAÍNA, TOCANTINS STATE, BRAZIL, FROM 1995 TO 2000. J. Venom. Anim. Toxins incl. Trop. Dis., 2005, 11, 4, p. 432

9 GARCIA FCM., FULINI DR., MENDES RP., BARRAVIERA B., MARCONDESMACHADO J., PEREIRA PCM., SOUZA LR., ZORNOFF DCM., MEIRA DA. Estudo clínico-epidemiológico de doentes picados por serpentes venenosas, na região de Botucatu. J. Bras. Med., 1994, 67, 224-32.

10 JORGE MT., RIBEIRO LA. Acidentes por animais peçonhentos. In: AMATO NETO V., BALDY JLS. Doenças transmissíveis. São Paulo: Sarvier, 1989: 133-41.

11 KOUYOUMDJIAN JA., POLIZELLI C. Acidentes ofídicos causados por Bothrops moojeni: correlação do quadro clínico com o tamanho da serpente. Rev. Inst. Med. Trop. S. Paulo, 1989, 31, 84-90.

12 LEBRÃO ML., RIBEIRO LA., JORGE MT. Avaliação dos óbitos por acidentes por serpentes peçonhentas no Estado de São Paulo, 1988/1989. Rev. Ass. Méd. Bras., 1995, 41, 343-7.

13 MARTINEZ EG., VILANOVA MCT., JORGE MT., RIBEIRO LA. Aspectos epidemiológicos do acidente ofídico no Vale do Ribeira, São Paulo, 1985 a 1989. Cad. Saúde Públ., 1995, 11, 511-5.

14 NASCIMENTO SP. Aspectos epidemiológicos dos acidentes ofídicos ocorridos no Estado de Roraima, Brasil, entre 1992 e 1998. Cad. Saúde Públ., 2000, 16, 271-6.

15 RiBeiro LA., AlbuQUeRQUe MJ., PIRES DE CAMPOS VAF., KATZ G., TAKAOKA NY., LEBRÃO ML., JORGE MT. Óbitos por serpentes peçonhentas no Estado de São Paulo: avaliação de 43 casos, 1988/1993. Rev. Ass. Méd. Bras., 1998, 44, 312-8.

16 RODRIGUES DS., TELES AMS., MACHADO MAML., VARGENS MML., NASCIMENTO IM., PLANZO TMP. Ofidismo na Bahia: um problema de saúde pública. Rev. Soc. Bras. Toxicol., 1988, 1, 23-6.

17 VÊNCIO D. Estudo do ofidismo em Goiás: comprometimento da função renal. Rev. Goiana Med., 1988, 34, 95-116. 